\title{
Spatio-Temporal Variation Characteristics of Water Quality and Its Response to Climate: A Case Study in Yihe River Basin
}

\author{
J. Y. Ren ${ }^{1,2,3}$, H. M. $\mathrm{Liu}^{2,3,4}$, S. Y. Ding ${ }^{2,3 *}$, and Z. H. Cao ${ }^{2,3,5}$ \\ ${ }^{l}$ State Key Joint Laboratory of Environmental Simulation and Pollution Control, China-Canada Center for Energy, Environment and Ecology \\ Research, UR-BNU, School of Environment, Beijing Normal University, Beijing 100875, China. \\ ${ }^{2}$ Key Laboratory of Geospatial Technology for the Middle and Lower Yellow River Regions, Henan University, Ministry of Education, Kaifeng 475004, China. \\ ${ }^{3}$ College of Geography and Environmental Science, Henan University, Kaifeng 475004, China. \\ ${ }^{4}$ Civil and Economic Law College, Henan University of Economics and Law, Zhengzhou 450000, China. \\ ${ }^{5}$ State Key Laboratory of Earth Surface Processes and Resource Ecology, Faculty of Geographical Science, Beijing Normal University, Beijing 100875, China.
}

Received 17 May 2021; revised 21 June 2021; accepted 29 July 2021; published online 16 August 2021

\begin{abstract}
Spatial-temporal patterns of river water quality, the identification of pollution sources and contaminated areas are crucial to water environment protection and sustainable development of the river basin. In this study, spatial-temporal characteristics of river water quality in the Yihe river basin were investigated through multivariate analysis methods, including principal component analysis (PCA), cluster analysis (CA), discriminant analysis (DA), and one-way ANOVA. The water quality indicators (Hydrogen ion concentration $(\mathrm{pH})$, electric conductivity (EC), dissolved oxygen (DO), turbidity, chemical oxygen demand (COD), total phosphorus (TP), and ammonia nitrogen $\left(\mathrm{NH}_{4}{ }^{+}-\mathrm{N}\right)$ ) were investigated at 17 sampling sites in three periods (i.e., high-, mean-, low flow period) during $2016 \sim$ 2017. The results show that: (1) PCA served to extract and recognize the most significant indicators affecting water quality in the Yihe river basin, i.e., $\mathrm{pH}, \mathrm{EC}, \mathrm{COD}$, and $\mathrm{NH}_{4}{ }^{+}-\mathrm{N}$. (2) CA divided the Yihe river basin into three groups with similar water quality features, namely the upper, middle, and lower reaches. (3) DA demonstrated strong dimensionality reduction ability with the accuracy of clustering was $94.1 \%$, and only a few indicators (i.e., DO, EC, turbidity, $\mathrm{NH}_{4}{ }^{+}-\mathrm{N}$, and TP) could reflect the spatial variations in water quality. (4) One-way ANOVA indicated that the water quality was the worst in the lower reach of Yihe river basin during the mean-flow period, followed by which in the upper and middle reaches during the high-flow period. (5) The spatiotemporal characteristics of water quality were mainly restrained by human factors (e.g., the construction of highway and agricultural activities), climate change (e.g., precipitation and temperature), and natural environments (e.g., topography).
\end{abstract}

Keywords: river water quality, spatial-temporal characteristics, multivariate statistical analysis, Yihe River Basin, climate change

\section{Introduction}

Rivers are the most important water bodies on land (Oki and Kanae, 2006; Vörösmarty et al., 2010), and most ancient civilizations in the world are originated in large river basins (Mir and Gani, 2019). Excellent water quality and adequate water quantity are critical to human health (Pejman et al., 2009; Zhang et al., 2012) and the sustainable development of the economy in the river basin (Ravindra et al., 2003; Wu et al., 2018). Humans have made the best use of water resources through industrialization, irrigation, and engineering measures (e.g., dams, reservoirs and water transfer across river basins) (Oki and Kanae, 2006; Wang et al., 2016). However, the demand for high-quality water resources is growing consistently, nearly $80 \%$ of the world's population still faces serious water security threats (Oki and Kanae, 2006; Vörösmarty et al., 2010). River is the most vul-

* Corresponding author. Tel.: 0371-23881850; Fax: 0371-23881850.

E-mail address: syding@henu.edu.cn (S. Y. Ding).

ISSN: 2663-6859 print/2663-6867 online

(C) 2021 ISEIS All rights reserved. doi:10.3808/jeil.202100070. nerable water body to contain pollution from agricultural runoff, domestic and industrial sewage (Singh et al., 2005; Varol et al., 2012; Wang et al., 2013; Liu et al., 2019; Chaudhuri et al., 2020) under the multiple effects of natural processes (e.g., climate change, soil erosion, and weathering of bedrock) (Vega et al., 1998; Oketola et al., 2013; Shrestha and Wang, 2020), human activities (e.g., agricultural, urban and industrial activities) (Vitousek et al., 1997; Paul and Meyer, 2001; Sickman et al., 2007; Zhang et al., 2018; Yu et al., 2020), and increasing water demand (Vörösmarty et al., 2010). With the increasing degradation of river water quality, including eutrophication, organic matter, and heavy metal pollution (Vitousek et al., 1997; Carpenter et al., 1998), its disastrous impacts on drinking water safety, industrial and agricultural production, and aquatic biodiversity have attracted wide attention (Carpenter et al., 1998; Wang et al., 2017). Consequently, it is particularly important to control river pollution and prevent the degradation of river water quality. Moreover, previous study revealed that water quality is apparently spacetime dependence, thus it is necessary to monitor and evaluate the river water quality in the river basin in different periods (Strobl et al., 2008; Pérez et al., 2017; Sinha et al., 
2019). Climate change also impacts water quality directly or indirectly, such as associated changes in precipitation patterns (i.e., precipitation amount, intensity, and frequency) affect the mount of nitrogen transported to downstream water bodies (Sinha and Michalak, 2016; Sinha et al., 2019). To help the provincial government protect the river water environment and control river pollution, it is very crucial to conduct a thorough examination of the spatio-temporal characteristics of water quality and the associated influencing factors based on monitoring data.

Previously, a number of efforts about water quality in river basins have been made in many countries and regions, through which the spatiotemporal similarities and differences of varies water quality indicators were analyzed at different sampling points over multiple periods (Vitousek et al., 1997; Ravindra et al., 2003; Bellos and Sawidis, 2005; Singh et al., 2005; Kannel et al., 2007; Sickman et al., 2007; Varol et al., 2012; Wang et al., 2013; Putro et al., 2016; Rigi et al., 2019). Multivariate statistical analysis methods are reliable tools for water quality assessment and water pollution problem treatment (Singh et al., 2004, 2005; Igibah and Tanko, 2019). Due to their excellent performance in reducing the data dimension, extracting potential information, and verifying the spatial and temporal changes in water quality, multivariate statistical tools such as principal component analysis (PCA), factor analysis (FA), cluster analysis (CA), discriminant analysis (DA) and one-way analysis of variance (ANOVA) have been widely used to handle the massive and complex water quality data that generated through the water environment monitoring projects. Numbers studies were devoted to identify the spatiotemporal variation of river water quality (Simeonov et al., 2003; Singh et al., 2005; Sundaray et al., 2006; Shrestha and Kazama, 2007; Varol et al., 2012; Li et al., 2017; Zhu et al., 2018; Mir and Gani, 2019; Sun et al., 2019) and the water environment assessment of groundwater (Andrade et al., 2008; Zhang et al., 2012), coastal water body (Zhou et al., 2007), and lakes (Pejman et al., 2009; Wu et al., 2018).

The Yiluo River is the combined name of Yihe River and Luohe River, which is the largest tributary below the Yellow River Sanmenxia Reservoir. The water quality directly affects the sustainable development of economy and society of the Yihe River Basin. However, in most of the previous studies, several related studies in Yiluo River Basin were mainly focused on heavy metal pollution (Yan et al., 2016), relationships between aquatic organisms and water environment factors (Lin et al., 2019), and effects of landscape spatial heterogeneity on water quality (Yu et al., 2014; Liu et al., 2019). There has no report in studying the spatiotemporal characteristics of water quality in typical small watersheds in the Yihe River Basin. Furthermore, only a handful studies have surveyed the combined effects of land use variation and climate change on water quality, and these have only been conducted in individual river basins (Tu, 2009).

Therefore, as the extension of previous studies, the objective of this study is to analyze the spatiotemporal characteristics of water quality in the Yihe River Basin through multiple statistical methods, as well as the potential causes of pollution. In detail, (1) measuring the water quality data targeting on six indicators (i.e., $\mathrm{pH}, \mathrm{EC}, \mathrm{DO}, \mathrm{COD}, \mathrm{TP}$ and $\mathrm{NH}_{4}{ }^{+}-\mathrm{N}$ ) that monitored in 17 typical sub-basins in Yihe River Basin during three water periods (i.e., high-, mean-, low flow period) from 2016 to 2017 ; (2) analyzing the spatiotemporal characteristics of water quality through four multiple statistical methods (i.e., PCA, CA, DA and ANOVA); (3) investigating the potential factors that effecting the water quality of the Yihe River Basin (such as human activities, climate change and natural environment). The results are expected to provide a scientific basis for water re-source management, utilization, and ecological environment pro-tection in the Yihe River Basin.

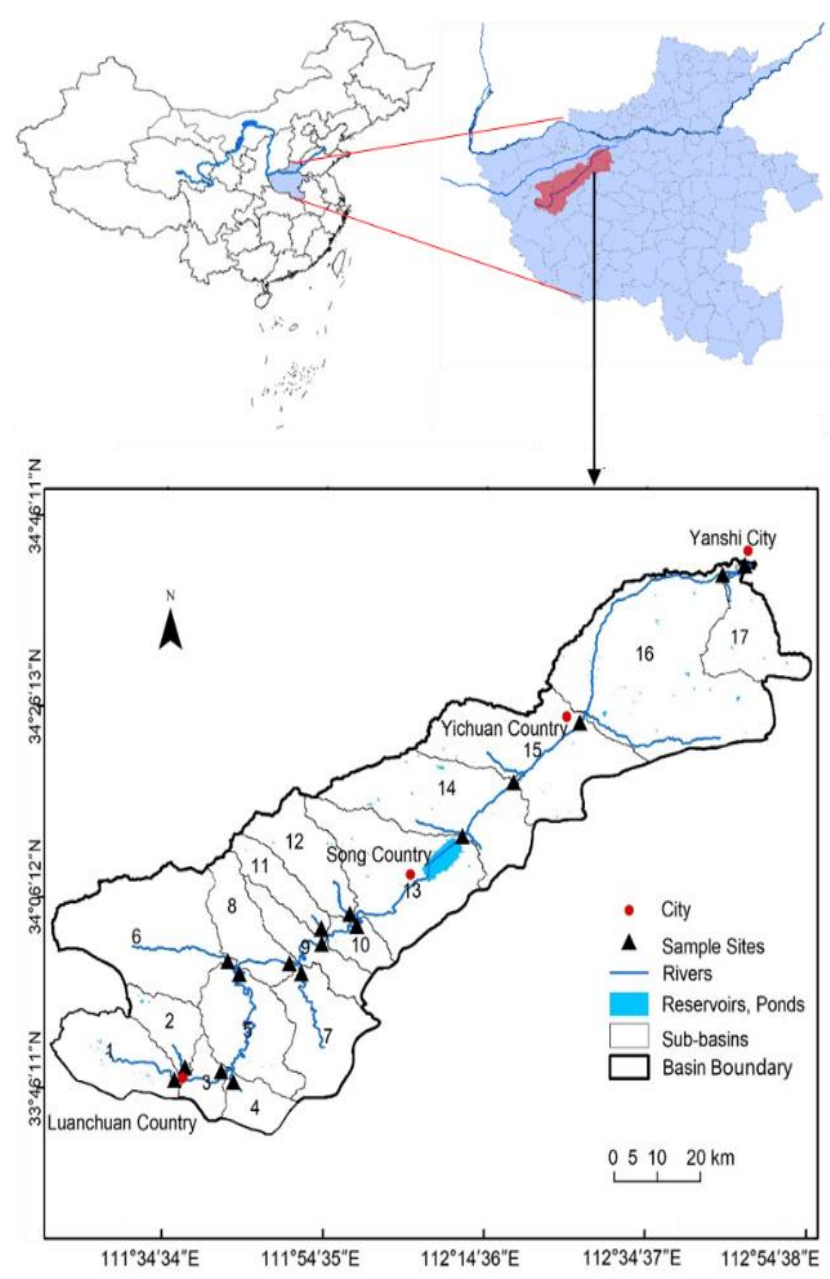

Figure 1. Location of sampling sites and sub-basins in Yihe River basin.

\section{Overview of the Study Area}

The Yihe River Basin is one of the major regions in the Yel-low River Basin over China $\left(33^{\circ} 39^{\prime} \sim 34^{\circ} 41^{\prime} \mathrm{N}, 111^{\circ} 19^{\prime} \sim\right.$ $112^{\circ} 54^{\prime} \mathrm{E}$ ) (Figure 1). The extent of the Yihe River Basin and 17 typical sub-basins were extracted through the Arc SWAT hydrological analysis module (Ren, 2018). These extracted basins were based on the digital elevation model (DEM) data with a precision of $30 \mathrm{~m}$ (http://henu.geodata.cn), river network and terrain features (e.g., slope and altitude). Yihe River Basin is a transitional section of China's topography ladder from the second step to the third one, with an elevation from 109 to $2159 \mathrm{~m}$, 
Table 1. Statistical Description of Water Quality Indicators in the Yihe River Basin

\begin{tabular}{|c|c|c|c|c|c|c|c|c|c|c|c|c|c|}
\hline & \multicolumn{3}{|c|}{ Low-Flow Period } & \multicolumn{4}{|c|}{ Mean-Flow Period } & \multicolumn{3}{|c|}{ High-Flow Period } & \multirow[b]{2}{*}{ Mean } & \multirow[b]{2}{*}{ Std. } & \multirow[b]{2}{*}{ Units } \\
\hline & Max & Min & Mean & Std. & Max & Min & Mean & Std. & Max & Min & & & \\
\hline$\overline{\mathrm{pH}}$ & 8.55 & 7.14 & 7.89 & 0.31 & 8.45 & 7.00 & 8.00 & 0.40 & 8.50 & 6.14 & 7.88 & 0.57 & - \\
\hline EC & 840.50 & 209.50 & 577.32 & 154.44 & 916.00 & 354.50 & 604.82 & 160.92 & 816.00 & 383.00 & 599.51 & 132.04 & $\mu \mathrm{s} \bullet \mathrm{cm}^{-1}$ \\
\hline DO & 13.38 & 4.43 & 9.51 & 2.09 & 12.44 & 7.36 & 9.26 & 1.33 & 11.96 & 4.42 & 8.35 & 1.72 & $\mathrm{mg} \cdot \mathrm{L}^{-1}$ \\
\hline Turbidity & 28.35 & 0.42 & 13.17 & 9.57 & 20.00 & 0.77 & 13.69 & 6.88 & 19.91 & 3.33 & 10.36 & 5.15 & NTU \\
\hline COD & 71.47 & 7.91 & 37.46 & 19.78 & 33.50 & 2.70 & 18.68 & 9.81 & 25.75 & 4.45 & 12.56 & 5.92 & $\mathrm{mg} \cdot \mathrm{L}^{-1}$ \\
\hline $\mathrm{NH}_{4}{ }^{+}-\mathrm{N}$ & 4.72 & 0.11 & 0.73 & 1.06 & 19.72 & 0.55 & 4.69 & 4.87 & 3.09 & 0.06 & 0.41 & 0.74 & $\mathrm{mg} \cdot \mathrm{L}^{-1}$ \\
\hline $\mathrm{TP}$ & 0.15 & 0.00 & 0.03 & 0.03 & 0.10 & 0.01 & 0.03 & 0.03 & 0.14 & 0.00 & 0.02 & 0.03 & $\mathrm{mg} \cdot \mathrm{L}^{-1}$ \\
\hline
\end{tabular}

Table 2. Single Sample K-S Inspection

\begin{tabular}{|c|c|c|c|c|c|c|c|c|}
\hline & & $\mathrm{pH}$ & $\mathrm{EC}$ & DO & TUR & $\mathrm{COD}$ & $\mathrm{NH}_{4}{ }^{+}-\mathrm{N}$ & TP \\
\hline \multirow[t]{2}{*}{ Normal Indicators $\mathrm{a}, \mathrm{b}$} & Mean & 7.92 & 596.54 & 9.16 & 12.41 & 22.90 & 1.94 & 0.02 \\
\hline & Standard deviation & 0.35 & 111.81 & 1.15 & 5.27 & 8.40 & 1.89 & 0.03 \\
\hline \multirow[t]{3}{*}{ Most Extreme Difference } & Absolute value & 0.26 & 0.17 & 0.19 & 0.15 & 0.13 & 0.28 & 0.28 \\
\hline & Positive & 0.10 & 0.17 & 0.19 & 0.11 & 0.13 & 0.28 & 0.25 \\
\hline & Negative & -0.26 & -0.11 & -0.09 & -0.15 & -0.11 & -0.21 & -0.28 \\
\hline \multicolumn{2}{|l|}{ Kolmogorov-Smirnov Z } & 1.06 & 0.70 & 0.77 & 0.60 & 0.52 & 1.17 & 1.15 \\
\hline \multicolumn{2}{|c|}{ progressive significance (both sides) } & 0.22 & 0.71 & 0.59 & 0.86 & 0.95 & 0.13 & 0.14 \\
\hline
\end{tabular}

a. The test distribution is normally distributed; b. Calculated based on data.

Table 3. Principal Component Loading Matrix of Low-, Mean-, and High-Flow in Yihe River Basin

\begin{tabular}{|c|c|c|c|c|c|c|c|c|}
\hline \multirow[t]{2}{*}{ Indicators } & \multicolumn{3}{|c|}{ Low-Flow Period } & \multicolumn{2}{|c|}{ Mean-Flow Period } & \multicolumn{3}{|c|}{ High-Flow Period } \\
\hline & $\mathrm{PC} 1$ & $\mathrm{PC} 2$ & $\mathrm{PC} 3$ & $\mathrm{PC} 1$ & $\mathrm{PC} 2$ & $\mathrm{PC} 1$ & $\mathrm{PC} 2$ & $\mathrm{PC} 3$ \\
\hline $\mathrm{pH}$ & -0.803 & 0.179 & 0.164 & 0.894 & 0.060 & 0.939 & -0.051 & -0.006 \\
\hline $\mathrm{EC}$ & 0.849 & 0.304 & -0.046 & 0.379 & 0.707 & 0.840 & -0.084 & 0.238 \\
\hline DO & -0.458 & -0.078 & 0.393 & 0.142 & 0.633 & -0.123 & -0.030 & 0.864 \\
\hline Turbidity & 0.048 & 0.262 & 0.836 & 0.320 & -0.696 & 0.939 & -0.070 & -0.188 \\
\hline COD & 0.022 & 0.897 & 0.170 & 0.322 & 0.755 & 0.078 & 0.889 & 0.010 \\
\hline $\mathrm{NH}_{4}{ }^{+}-\mathrm{N}$ & 0.731 & 0.045 & 0.099 & 0.857 & 0.235 & -0.253 & 0.806 & -0.123 \\
\hline TP & 0.163 & 0.608 & -0.654 & 0.741 & 0.113 & 0.493 & -0.122 & 0.563 \\
\hline Eigenvalue & 2.363 & 1.327 & 1.173 & 2.989 & 1.492 & 2.947 & 1.426 & 1.076 \\
\hline Variance contribution rate $(\%)$ & 30.569 & 19.644 & 19.266 & 35.042 & 28.970 & 40.137 & 20.989 & 16.710 \\
\hline Accumulating contribution rate (\%) & 30.569 & 50.213 & 69.479 & 35.042 & 64.012 & 40.137 & 61.126 & 77.837 \\
\hline
\end{tabular}

with an area of $5.54 \times 10^{3} \mathrm{~km}^{2}$. The mountainous area accounts for $53.4 \%$, the hilly area accounts for $35 \%$, and plains and the river valley account for $11.6 \%$ (Ren, 2018). Therefore, the main landscape of the Yihe River Basin is the mountain landscape. Yihe River originates from Menton Ridge, Sanhe Village, Taowan Town, Luanchuan County, south of Xiong'er Mountain, and locates in Luoyang City, Henan Province, China. The river flows from the southwest to the northeast, and through Song Country, Yichuan country, and Luoyang City from the source, and finally injects into Luohe River in Yang Village, Yanshi Country. The length of the main river is $2.68 \times 10^{2} \mathrm{~km}$, and the annual average run-off volume is $1.27 \times 10^{9} \mathrm{~m}^{3}$. Yihe River Basin locates in a temperate continental monsoon climate zone, which have cold-dry winters and hot-humid summers. The annual average temperature varies from $12.4{ }^{\circ} \mathrm{C}$ (southwest) to $15.2{ }^{\circ} \mathrm{C}$ (northeast) (Ren et al., 2017). The annual average precipitation ranges 700 (northeast) to $900 \mathrm{~mm}$ (southwestern), approximately $50 \%$ of which is concentrated in July to September. Rainstorms were often occurred during summer, which would trigger disasters such as floods and mudslides (Liu et al., 2019). Cinnamon soil, brown soil, adamic earth and skeletal soil are the main soil types of Yihe River Basin.

\subsection{Water Quality and Climate Change Data}

Given the operability of sampling and the representativeness of the output of sampling points in the sub-basin, the exits of these 17 sub-basins are exactly the planned sampling sites. A total of six times samples were taken from December 2016 to August 2017 according to the hydrological regularity and the characteristics of multi-year precipitation in the Yihe River Basin: Twice during the low-flow period (December 2016 to January 2017), twice during the mean-flow period (April to May 2017), and twice during high-flow period (July to August 2017). These samples were taken once a month. Following previous studies (GonzalesInca et al., 2015; Li et al., 2017; Zhang et al., 2018) and the main landuse types, seven river water quality indicators were selected in the Yihe River Basin, including $\mathrm{pH}$, EC, DO, turbidity, COD, $\mathrm{NH}_{4}{ }^{+}-\mathrm{N}$, and TP, Table 1 presents their specific statistical descriptions. Water samples at each sampling point in the sub-basin were collected in a pretreated polyethylene bottle and stored in a sampling box at $4{ }^{\circ} \mathrm{C}$. The values of $\mathrm{pH}, \mathrm{EC}$ and DO were measured on-site with the SX713 portable measuring instrument (Runsun Instruments Inc., Chengdu, China). Turbidity was measured on-site using the portable GZ- 
20B turbidimeter (Fenglin Technology Inc., Shanghai, China). The location of the sampling point and the peripheral environment were also recorded at the same time. The residual three indicators (i.e., $\mathrm{COD}, \mathrm{NH}_{4}{ }^{+}-\mathrm{N}$ and TP) were examined through the 5B-6 (C) triple-parameter measuring instrument (Lianhua Technology Inc., Beijing, China) as soon as possible after all water samples have been brought back to the laboratory within 24 hours.

(a) Cluster dendrogram based on hierarchical cluster analysis

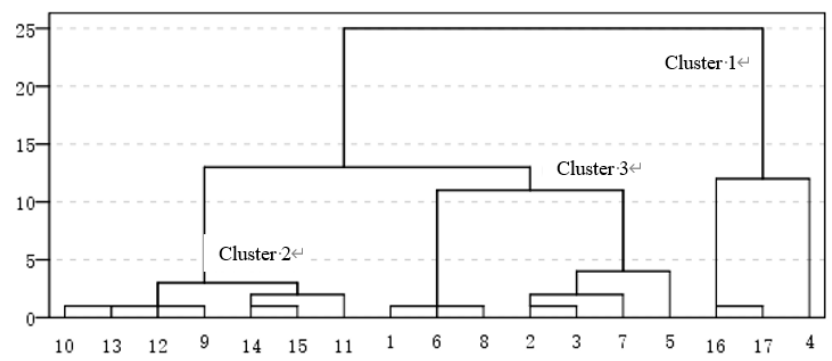

(b) Spatial distribution map of cluster groups in Yihe River Basin

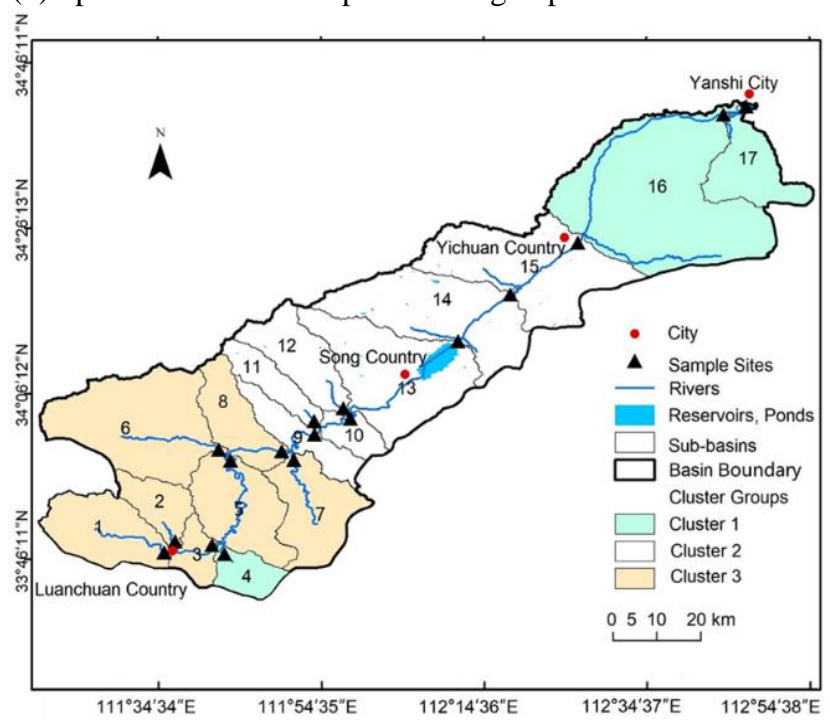

Figure 2. Cluster dendrogram of the sampling sites based on water quality indicators.

From our previous studies (Liu et al., 2017), climate change had close direct or indirect associations with the investigated water quality. This study focused on analyzing the spatio-temporal associations between river water quality and potential influencing factors of water pollution, such as climate changes (i.e., precipitation and temperature) in Yihe River Basin. To do this, the observed monthly precipitation and temperature data at four weather stations (i.e., Luanchuan Country, Song Country, Yichuan Country, and Yanshi city) from 1998 to 2017 were collected in the Statistical Yearbook (Luoyang Statistical Yearbook).

\subsection{Multivariate Statistical Analysis Methods}

In this study, PCA, CA, DA and ANOVA were used to evaluate the spatiotemporal characteristics of water quality in Yihe
River Basin. Multivariate statistical analysis requires that the pollution indicators have a normal or near-normal distribution (Sun et al., 2013; Mavukkandy et al., 2014). The single-sample Kolmogorov-Smirnov test method (Liu et al., 2003; Rigi et al., 2019) was used to analyze the distribution characteristics of pollutant concentrations in the water samples. When $\alpha=0.05$ and $\alpha=0.01$, the cutoff values of Kolmogorov-Smirnov (K-S) test statistic $Z$ (Kolmogorov-Smirnov $Z$ ) were 1.36 and 1.63, respectively. When the bilateral asymptotic significance probability Sig < $\alpha$, reject the null hypothesis, otherwise accept.

The PCA performance well on the dimensionality reduction of complex data. Several comprehensive factors that reflect the majority of original data could be examined through linear transformation. It also has a significant ability in identifying the types and sources of major pollutants in different study periods (Vega et al., 1998; Simeonov et al., 2003). There are six key steps: normalizing the original data, constructing the correlation coefficient matrix, acquiring the eigenvalues and eigen-vectors, identifying the principal component contribution rate and cumulative contribution ratio, calculating the principal component load, and examining the score of each principal component (Ma et al., 2015).

CA is an unsupervised pattern recognition technology, which can quantitatively determine the kinship relationship between a batch of samples without prior assumptions (Vega et al., 1998; Varol et al., 2012). Hierarchical cluster analysis (HCA) is one of the most general CA to classify water quality indicators into cluster groups according to their similarity or nearness (Igibah and Tanko, 2019). HCA has two forms, there are Q-type clustering (i.e., classifying samples) and R-type clustering (i.e., classifying observed variables of the research object). In this study, Q-type clustering method was used to measure the distance between samples and generate the clustering tree diagram. The method is based on the squared Euclidean distance and the Ward algorithm (Strobl et al., 2008).

DA can be used to distinguish cluster analysis results and determine primary pollution indicators. There are three main types: standard, forward and backward. Among them, the backward discriminant analysis method has a better ability to reduce the dimension and discriminate of the indicators. As a result, the backward discriminant analysis method was used to analyze the spatial difference of water quality in the Yihe River Basin, and the cross-validation method was chosen to test its discriminative ability.

ANOVA is a very useful tool for analyzing datasets, which can be classified into two categories one-way and multiway ANOVA. The controlling factors of water quality changes in the Yihe River Basin are mainly time and space. A one-way analysis of variance can be performed. The significance test formula as follows:

$$
F=\frac{S S A /(k-1)}{S S E /(n-k)}
$$

where $k$ is the number of levels, $n$ is the number of samples, $S S A$ is the sum of squared spreads between groups, and SSE is the 
sum of squared deviations within groups. The $F$ statistic obeys the $F$ distribution with degrees of freedom $(k-1, n-k)$. When the corresponding associated probability value is less than the significance level $\alpha$ (usually 0.05 ), the null hypothesis is rejected, indicating that the population means have significant differences at different levels of the control variable. Otherwise, there are no significant differences. The above analysis was done collaboratively using Microsoft Excel 2007 and SPSS 20.0.

\section{Results}

\subsection{Evaluation of Water Quality}

Table 2 shows the result of the sample K-S test for each water quality indicator. Progressive significance values (both sides) for each indicator are greater than 0.05 , indicating that overall river water quality indicators in 17 typical sub-basins over the Yihe River Basin conforms to the normal distribution. Thus, the monitored river water quality data can be used for multivariate statistical analysis.

\subsection{Temporal Variation Characteristics of River Water Quality in Yihe River Basin}

Temporal variation characteristics of seven river water quality indicators in 17 typical sub-basins were analyzed through the PCA (Table 3). KMO and Bartlett Spheroid tests showed that the principal component analysis was effective $(d f=21, P<0.01)$.

The extracted principal components could reflect the basic situation of the original data (Liu et al., 2003; Simeonov et al., 2003). Three principal components (PCs) were extracted during the low- and high-flow period, and two PCs were extracted during the mean-flow period according to the principle (i.e., eigenvalue is greater than 1). Based on previous studies (Liu et al., 2003; Hussain et al., 2021), the absolute value of PCs that above 0.70 in this study was used as a criterion for determining highload values (Table 3, Bold font). Then, the water quality variations during different water periods in the Yihe River Basin can be explained and discussed as follows. The absolute values of the PCs load of COD, $\mathrm{NH}_{4}{ }^{+}-\mathrm{N}, \mathrm{EC}$ and $\mathrm{pH}$ were greater than 0.7 in the three periods (Table 3). It indicated that $\mathrm{COD}, \mathrm{NH}_{4}{ }^{+}$ $\mathrm{N}, \mathrm{EC}$ and $\mathrm{pH}$ were the most notable factors which affecting water quality throughout the study period in the Yihe River Basin. However, during low- and high-flow period, turbidity has a relatively higher PC load value. TP and DO have a strong correlation with the PC load value during the mean- and high-flow period, respectively.

During the low-flow period, the PC1 explained $30.57 \%$ of the water quality variation, which was much larger than the contribution rates of the variance of PC2 (19.64\%) and PC3 (19.27\%). EC and $\mathrm{NH}_{4}{ }^{+}-\mathrm{N}$ showed a strong positive correlation (correlation coefficient > 0.7) with the PC1, while $\mathrm{pH}$ and DO have a negative correlation with the $\mathrm{PC} 1$. EC is a comprehensive indicator of the degree of ion activity in water and the evaluation of ion quality (Zhang et al., 2012), which mainly reflects the impact of human activities and geological sediments in the water environment (Bellos and Sawidis, 2005; Yang et al., 2007; $\mathrm{Xie}$ et al., 2020). Generally, the value of $\mathrm{pH}$ in river water is weakly alkaline, which is mainly affected by external pollution sources and aquatic biological activities, and the $\mathrm{pH}$ can control the redox reaction of river water to a certain extent ( $\mathrm{Li}$ et al., 2017). The $\mathrm{pH}$ load value was negative, indicating that it was lower during the low-flow period. The content of DO is generally saturated in natural water, but it will decrease rapidly with the increase of biomass (Chang, 2005). When DO is less than $2 \mathrm{mg} \cdot \mathrm{L}^{-1}$, most fish cannot survive (Russo et al., 1981). The water quality indicator that strongly related to the PC2 was COD, while TP was generally weaker associated. COD characterizes the level of organic pollution in water bodies and is closely associated with wastewater discharge from urban, industrial, and agricultural activities (Bellos and Sawidis, 2005; Li et al., 2017). TP related to the input of pesticides, industrial wastewater, and agricultural activities (Kannel et al., 2007). The high values of COD and TP in the water would reduce the DO concentration and induce the deterioration of surface water quality (Kannel et al., 2007; Zhang et al., 2012; Li et al., 2017). Fang et al. (2013) have emphasized that agricultural non-point source pollution was relatively small during the low-flow period compared to point source pollution. Therefore, during the low-flow period, various pollutants that entered the Yihe River have formed the organic pollution, such as domestic sewage and industrial wastewater discharge. The decomposition process may consume a large amount of oxygen (the value of DO is negative, Table 3 ) and generate ammonia (higher $\mathrm{NH}_{4}{ }^{+}-\mathrm{N}$ value, Table 3), organic acids and carbon dioxide. The hydrolysis of these acidic substances leaded to a decrease in $\mathrm{pH}$, which was consistent with previous findings (Vega et al., 1998; Shrestha and Kazama, 2007). Consequently, the PC1 and PC2 can be classified as the combined effects of natural changes in the water environment and human activities (e.g., domestic and industrial wastewater discharge). Turbidity indicates the degree of resistance of suspended matter and colloids in water (such as soil, silt, and plankton) to light transmission (Wu et al., 2018). Turbidity has a strong positive correlation with PC3, which may be related to a large number of sand mining operations in the basin during the low-flow period.

When it comes to the mean-flow period, the variance contribution rate of the $\mathrm{PC} 1$ was $35.04 \%$, of which the larger factor loads were mainly occupied by $\mathrm{pH}, \mathrm{NH}_{4}{ }^{+}-\mathrm{N}$ and TP. River water quality at sub-basin scale was largely affected by the dual effects of natural processes and human activities (Oketola et al., 2013; Zhang et al., 2018; Mir and Gani, 2019). For example, short-term surface runoff from rainfall will bring non-point source pollution and domestic sewage that generated through agricultural activities into rivers, causing nitrogen and phosphorus pollution in the water body. Field investigations have found that spring cultivation in the Yihe River Basin was carried out from March to April every year. The chemical fertileizers (e.g., phosphorus and organic fertilizers) that were used in the cultivation of crops (e.g., peanuts, cotton, tobacco, and vegetables) would directly pollute rivers due to the erosion of rainfall and runoff. In addition, the denitrification of pathogenic microorganisms such as E. coli carried in organic fertileizers (e.g., livestock and poultry manure) and bacteria produced in the process of returning straw to the field also have 
contributed to nitrogen and phosphorus pollution in water (Jia and Zhang, 2015; Li et al., 2018; Wang et al., 2020; Yao et al., 2020). The variance contribution rate of PC2 is $28.97 \%$, which is primarily related to $\mathrm{EC}$ and $\mathrm{COD}$ and can be classified as the common impact of natural and human activities.

In terms of the high-flow period, $\mathrm{pH}$, turbidity and $\mathrm{EC}$ were the main influence factors of the PC1. In the process of high-intensity rainfall during the high-flow period, a large number of terrestrial materials that produced by agricultural activities and soil erosion will migrate into the river water body with rainwater and the surface runoff, polluting the surface water. Turbidity represents pollution that induced by rainfall events during the high-flow period, such as Erosion. The variance contribution rate of the PC1 was $40.14 \%$ (Table 3), which is much larger than the variance contribution rates of PC2 $(0.99 \%)$ and PC3 $(16.71 \%)$, indicating that the river water quality during the high-flow period was greatly affected by the combined effects of non-point source pollution and rainfall events. The load values of COD, $\mathrm{NH}_{4}{ }^{+}-\mathrm{N}$ of the PC2 was increased obviously in the high-flow period than the other two periods. During the high-flow period, not only the precipitation increased significantly, but also the farmers applied large amounts of fertilizer to crops, especially corn. Nitrogen that cannot be effectively used by the plants would finally enter river with rainfall-runoff or groundwater infiltration, resulting in an increasing of nitrogen content in river water bodies. Besides, the $\mathrm{NH}_{4}{ }^{+}-\mathrm{N}$ content that discharged into surface water was also much higher, which usually came from the manure of free ranges livestock and poultry in rural areas, domestic and industrial sewage. Thus, with the increase of water temperature in summer, bacteria and other microorganisms in the river will increase nitrification, reflecting the degree of nitrogen and organic pollution in water. The PC3 has a strong positive correlation with DO (Table 3 ). In addition, the average value of DO during the high-flow period was as low as 8.35 (Table 1). This might be due to the fact that the water body received large amounts of untreated domestic, industrial wastewater, and other sources of pollution, resulting in higher concentrations of pollutants in the water and higher microbial activity. These biological processes may further consume lots of oxygen in the water, such as the metabolic activities of microorganisms and the decay of aquatic organisms.

Water quality indicators that have a significant impact on river water quality in one period may have reduced influence in another period. In general, the main water quality indicators of the three water periods in the Yihe River Basin reflect the dual influences of human activities and the natural environment characteristics on water quality: the main polluted factors in the low-flow period were organic pollution and the variations of natural environment, followed by nitrogen pollution. Nitrogen was the leading factor in river water pollution during the mean-flow period, followed by organic and phosphorus pollution. Organic pollution and nitrogen were the main factors affecting river water quality in the high-flow period. At the same time, comparing the statistical description of the water quality indicators of the Yihe River Basin during the three periods (i.e., low-, mean- and high-flow period) (Table 1), it can be found that: the average values of $\mathrm{pH}$ in the three water periods were slightly alkaline, and the change range during the entire study period from 6.13 to 8.9 , which was basically within the range (6.5 9.0) which aquatic organisms can maintain their natural processes (Chang et al., 2012). The lowest value of $\mathrm{pH}$ (6.14) was appeared in the high-flow period, which might becaused by the decomposition of organic matter in wastewater discharge. Seasonal changes in $\mathrm{pH}$ did not show much difference. The maximum values of DO and COD were appeared in the low-flow period, while these of EC, turbidity and $\mathrm{NH}_{4}{ }^{+}-\mathrm{N}$ were distributed in the mean-flow period. The mean value of TP was higher in the low-flow and the mean-flow period relative to these in the highflow period, which is consistent with previous research (Li et al., 2018). These might be due to the decreased of precipitation and runoff in these two periods, and the hydraulic erosion which affected the concentration of TP in river water to a certain extent.

\subsection{Spatial Distribution Characteristics of River Water Quality in Yihe River Basin}

\subsubsection{Spatial Cluster Analysis}

Based on the monitored water quality indicators of the Yihe River Basin from 2016 to 2017, hierarchical cluster analysis was performed on the 17 typical sub-basins. After recalibrated the distance based on the cluster, the threshold 13 was selected to divide the sample points into three groups (Figure 2). The spatial similarity analysis of the sample points was operated to capture the spatial distribution characteristics of river water quality in the Yihe River Basin. The samples that included in each group were as follows: Cluster 1 (i.e., C1) $\{4,16$, and 17\}; Cluster 2 (i.e., C2) $\{9,10,11,12,13,14$, and 15\}; Cluster 3 (i.e., C3) $\{1,2,3,5,6,7$, and 8$\}$.

According to the river network map, sub-basins division map, field investigation, and sampling in the Yihe River Basin, it can be inferred that the water quality of the same cluster group was affected by similar pollution sources and natural backgrounds, and thus has similar characteristics: in detail, samples 16 and 17 included in $\mathrm{C} 1$ were mainly distributed in the lower plain rivers. The rivers in this group (C1) flow through agriculture area, are close to the urban area, and are more scattered in space than the other two groups. In recent years, with the reduction of cultivated land, the continuous increase of construction land (Ren et al., 2017), and the accumulation of pollution in the upper and middle reaches of rivers, the water quality in $\mathrm{C} 1$ has been seriously polluted by agriculture, industry, and domestic discharge. Affected by the domestic sewage and industrial wastewater of Luanchuan County and its tributaries, the water quality of sample 4 (C1) located in upstream was also poor. The C2 samples mainly flows through farmlands and towns in the middle reaches of the Yihe river. Along with the increase in construction and forest land in $\mathrm{C} 2$, and the decrease of cultivated land and grassland (Ren et al., 2017), the water quality in this region was affected by both urbanization and agricultural activities. The sample points of $\mathrm{C} 3$ were belong to the upper reaches of the forest area and located at the southern foot of the Xiong'er Mountain. There was less human disturbance in this area, so the river was clean. The water quality of the above three groups (i.e., C1, C2, and C3) was all subject to human interference to varying degrees. 
Table 4. Eigenvalues of the Spatial Discriminant Analysis

\begin{tabular}{lllll}
\hline Typical Discriminant Function & Eigenvalues & Variance $(\%)$ & Accumulation $(\%)$ & Canonical Correlation Coefficient \\
\hline 1 & 22.817 & 93.4 & 93.4 & 0.979 \\
2 & 1.606 & 6.6 & 100.0 & 0.785 \\
\hline
\end{tabular}

Table 5. The Structure Matrix of the Characteristic Function of the Spatial Discriminant Analysis

\begin{tabular}{lll}
\hline Water Quality Indicators & Discriminant Function & 2 \\
\hline $\mathrm{TP}$ & 1 & -0.172 \\
$\mathrm{DO}$ & $0.274^{*}$ & -0.074 \\
$\mathrm{NH}_{4}{ }^{-} \mathrm{N}$ & $0.134^{*}$ & -0.094 \\
$\mathrm{COD}^{(\mathrm{a})}$ & $0.123^{*}$ & 0.008 \\
$\mathrm{EC}$ & $0.061^{*}$ & $0.525^{*}$ \\
Turbidity & 0.248 & $0.415^{*}$ \\
$\mathrm{pH}^{\text {(a) }}$ & 0.085 & $-0.085^{*}$ \\
\hline
\end{tabular}

Note: * represents the largest absolute correlation between a variable and a discriminant function; (a) indicates that the variable was not utilized in the analysis.

Table 6. Wilks' $\lambda$, Chi-Sqr, and Test of the Spatial Discriminant Analysis

\begin{tabular}{lllll}
\hline Function Test & Wilks' $\lambda$ & Chi-Sqr & $d f$ & Significant \\
\hline 1 to 2 & 0.016 & 45.410 & 14 & 0.000 \\
2 & 0.384 & 10.535 & 6 & 0.104 \\
\hline
\end{tabular}

\subsubsection{Discriminant Analysis}

To identify the water quality indicators that induced significant variations between groups, and to further verified the results of the above-mentioned spatial cluster analysis, the spatial characteristics of the three groups of water quality indicators were analyzed through DA (Tables 4,5 , and 6). The eigenvalues of the spatial discriminant analysis (Table 4) showed that the first discriminant function could explain almost all the variables $(93.4 \%)$. TP, $\mathrm{DO}, \mathrm{NH}_{4}{ }^{+}-\mathrm{N}$, and COD contribute higher to discriminant function 1 than other indicators (i.e., EC, turbidity and $\mathrm{pH}$ ). However, EC, turbidity, and $\mathrm{pH}$ contributed higher for the discriminant function 2 (Table 5). The value of Wilks' $\lambda$ and chi-square coefficient were $0.016 \sim 0.384$ and $10.535 \sim 45.41$ (Table 6), respectively. The significance test values $(0.000)$ of two discriminant functions were both less than 0.01, indicating that the spatial clustering analysis was reliable; the Wilks' $\lambda$ significance test value of discriminant function 2 is $0.104>$ 0.05 , which also showed the validity of discriminant functions of 1 and 2.

Table 7 exhibited the verification matrix of the discriminant analysis classification. The diagonal represented the number and proportion of samples that were predicted correctly, while the remainder denoted the number and proportion of samples which were incorrectly predicted. The overall accuracy of the grouping results of the clustering analysis was $94.1 \%$, indicating that it was reasonable to explore the characteristics of the spatial variation of water quality based on the clustering groups.

Table 8 showed the classification function coefficients of the linear discriminant function of Fisher. Based on Tables 4 and 8 , it can be inferred that the construction of the discriminant function involved five water quality indicators, including DO, EC, turbidity, $\mathrm{NH}_{4}{ }^{+}-\mathrm{N}$, and TP. These five water quality indicators not only implied that the discriminant function have a better ability to reduce the dimension of the indicators, but also showed that they have significant variations between there cluster groups (i.e., C1, C2, and C3). Therefore, the above five water quality indicators and discriminant functions could be used to characterize the spatial differences of water quality in the Yihe River Basin. The monitoring of such indicators needs to be strengthened in the future.

Table 7. Validation Matrix of the Classification by Means of Discriminatory Analysis

\begin{tabular}{llll}
\hline $\begin{array}{l}\text { Primitive } \\
\text { Group }\end{array}$ & Forecast Group & \\
\hline $\mathrm{C} 1$ & $3(100 \%)$ & 0 & $\mathrm{C} 3$ \\
$\mathrm{C} 2$ & 0 & $7(100 \%)$ & 0 \\
$\mathrm{C} 3$ & 0 & $1(14.3 \%)$ & $6(85.7 \%)$ \\
\hline
\end{tabular}

"C1" represents the sample points 4,16 , and 17 ; "C2" represents the sample points $9,10,11,12,13,14$, and 15 ; "C 3 " represents the sample points 1,2 , $3,5,6,7$, and 8 .

Table 8. Classification Function Coefficients of DA

\begin{tabular}{llll}
\hline \multicolumn{4}{l}{ Clustering Groups } \\
& 1 & 2 & 3 \\
\hline DO & 56.816 & 41.795 & 44.387 \\
EC & 1.591 & 1.392 & 1.358 \\
Turbidity & -7.758 & -6.375 & -6.782 \\
$\mathrm{NH}_{4}{ }^{-} \mathrm{N}$ & 14.764 & 14.837 & 15.416 \\
$\mathrm{TP}$ & 1552.138 & 260.377 & 471.095 \\
(Constant) & -2265.599 & -1723.768 & -1690.270 \\
\hline
\end{tabular}

\subsection{Spatiotemporal Variation Characteristics of Water Quality in Yihe River Basin}

The one-factor ANOVA analysis was performed for the 
water quality indicators during three time periods (i.e., low-, mean-, and high-flow period) and different space scales (i.e., $\mathrm{C} 1, \mathrm{C} 2$, and $\mathrm{C} 3$ ). Figure 3 presented the average value of water quality during the three periods under the three clustering groups in the Yihe River Basin. It can be found that EC, DO, turbidity, $\mathrm{NH}_{4}{ }^{+}-\mathrm{N}$, and TP revealed significant spatial and temporal differences, except for the two indicators of $\mathrm{pH}$ and COD (Figure 3 ). This verified the results of discriminant analysis to some extent, which also further confirmed that there were significant differences among clusters.

According to the variations of the water quality indicators during the three monitoring periods, it was interesting to find that: DO and $\mathrm{NH}_{4}{ }^{+}-\mathrm{N}$ were significantly different in the highflow period, respectively; turbidity presented notable difference in the mean-flow period; EC revealed an apparent difference between the low-flow period and mean-flow period; TP showed significant differences in the three periods of low-, mean-, and high-flow. The averaged values of water quality indicators in most clusters $(\mathrm{C} 1$ : $\mathrm{EC}$, turbidity and TP; $\mathrm{C} 2$ : DO and $\mathrm{NH}_{4}{ }^{+}-\mathrm{N}, \mathrm{C} 3$ : turbidity, $\mathrm{NH}_{4}{ }^{+}-\mathrm{N}$ and TP) showed a trend of mean-flow period $>$ low-flow period $>$ high-flow period; the averaged values of DO-C1, DO-C3, turbidity-C2, $\left(\mathrm{NH}_{4}{ }^{+}-\mathrm{N}\right)$ $\mathrm{C} 1$ and TP-C2 presented a trend of low-flow period $>$ meanflow period $>$ high-flow period; the averaged value of EC-C3 showed a trend in the low-flow period > high-flow period $>$ mean-flow period; the averaged value of EC-C2 revealed a trend of high-flow period > mean-flow period > low-flow period. Among the seven monitoring river water indicators, the maximum averaged value of four indicators (i.e., EC, turbidity, $\mathrm{NH}_{4}{ }^{+}-\mathrm{N}$, and TP) were appeared in the mean-flow period; and these of two indicators (COD and DO) were distributed in the low-flow period; only the maximum value of the averaged $\mathrm{pH}$ was monitored during the high-flow period. In general, river water pollution was the most serious during the meanflow period, followed by the low-flow period, and the water quality was best in the high-flow period.

The variation of the mean values of the seven water quality indicators (i.e., $\mathrm{pH}, \mathrm{EC}, \mathrm{DO}$, turbidity, $\mathrm{COD}, \mathrm{NH}_{4}{ }^{+}-\mathrm{N}$ and TP) during the same period in different spatial clusters (i.e., C1, C2 and C3) indicated that the water quality of the Yihe River Basin displayed a gradual decline trend from upstream to downstream. Moreover, the water quality characteristics of the three clustering groups were closely related to their spatial location. The maximum averaged values of the EC, TP, DO and turbidity were occurred in $\mathrm{C} 1$, which flows through agriculture land and urban area in the lower reaches of the river basin. Besides, EC, TP in $\mathrm{C} 1$ showed significant differences with the other two groups. The averaged value of TP in $\mathrm{C} 1$ was higher than the other two groups, and the difference between $\mathrm{C} 2$ and $\mathrm{C} 3$ was not significant. The DO and turbidity in $\mathrm{C} 1$ were significantly different from the other two groups in the high-flow and low-flow periods, respectively. The minimum value of the mean concentration of $\mathrm{NH}_{4}{ }^{+}-\mathrm{N}$ was appeared in $\mathrm{C} 2$, which was significantly different from $\mathrm{C} 1$ in the high-flow period. The water quality indicators (except TP) in the upper reaches of the forest area (C3) were lower than those of the other two groups, indicating that C3 was less subjected to human interference and the water quali- ty was better. Therefore, the regions with relatively severe pollution could be identified based on the average concentration of the above five water quality indicators and their spatial differrence. For instance, the averaged values of EC, TP, DO and turbidity were much higher in $\mathrm{C}$, and they also have significant differences with the water quality in the middle and upper reaches $(\mathrm{C} 2, \mathrm{C} 3)$. The poor water quality in $\mathrm{C} 1$ may be induced by industrial pollution and agriculture non-point source pollution in the area, as well as the accumulation pollution from the middle and upper reaches $(\mathrm{C} 2, \mathrm{C} 3)$.

\section{Discussion}

\subsection{Temporal Variation Characteristics and Its Response to Climate Change}

Generally, river water quality was the worst in the lowflow period and was better in the high-flow period (Yang et al., 2007). However, the overall water quality of the Yihe River Basin was the worst in the mean-flow period, followed by the low-flow period, while it was the best in the high-flow period. The river water quality may be significantly affected when the peripheral land-use type changed from natural to urban land (Tu and Xia, 2006; Shen et al., 2011; Putro et al., 2016). The construction of the highway from Luanchuan Country to Lushi Country highway in the upstream reaches was started during the low-flow period (Henan Government, 2017), and the landuse changes caused by which might be one of the main influencing factors of the poor water quality during this period. Luanchuan County is a mountainous landform, the roads, farmland, and residential areas of which were mainly distributed along the river valley. The development of the highway construction project has promoted the conversion of land-use types such as cultivated land and residential areas along with the river reserves to roads. This process would not only cause soil erosion but also directly affect the water quality of the adjacent river. The bare soil produced by this project would be washed into the river water body through surface runoff. Besides, the highway in this area mainly constructed in the form of high subgrades. Construction waste (e.g., waste slag, magma, and silt), road runoff, and flying dust that generated in the process of subgrades filling would easily enter the river. Thus, the turbidity of the river water was apparently increased, and finally induce the reduction of the quality in river water. At the same time, the aquatic ecological control project was carried out in the Song Country urban area and the Yichuan Country in the middle reaches during the mean-flow period. The project promoted the input of pollutants into the Yihe River, which made the concentration values of turbidity, $\mathrm{NH}_{4}{ }^{+}-\mathrm{N}$ and $\mathrm{TP}$ of $\mathrm{C} 3$ and $\mathrm{C} 1$ were much higher during the mean-flow period than those in low- and high-flow period and affected the river water quality.

During the low-flow period, the water quality of the Yihe River Basin was also relatively poor. Previously, precipitation was widely regarded as one of the most powerful meteorological inputs in hydrological and water quality (Sajjad et al., 2018; Solakian et al., 2019). Figure 4 shows the averaged values of the monthly precipitation and temperature at four weather stations (i.e., Luanchuan Country, Song Conntry, Yichuan Country 
(a)

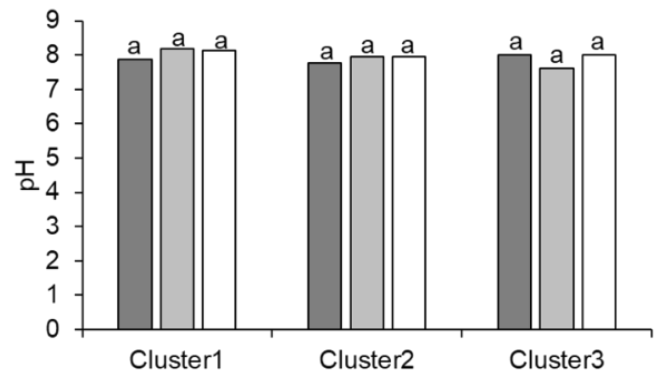

(c)
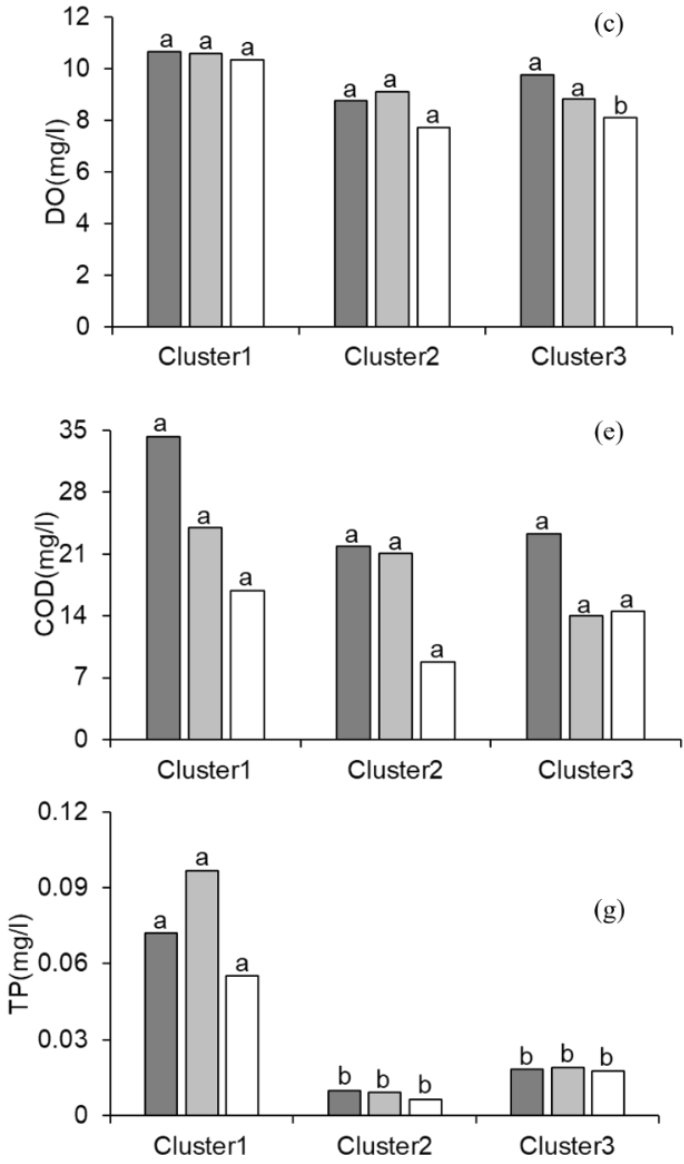

(b)

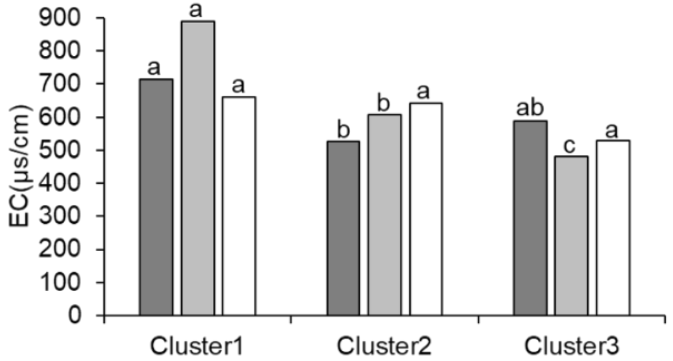

(d)
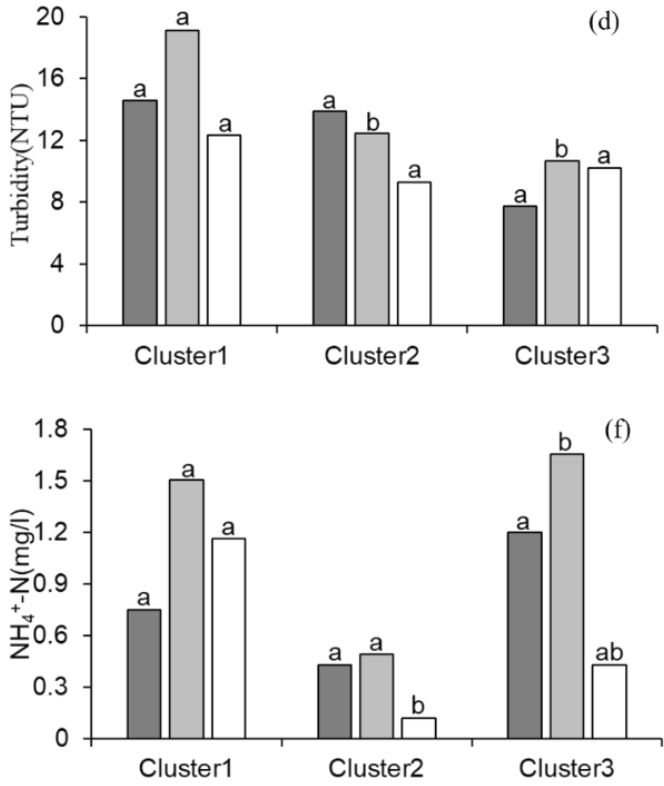

口Low-flow period

口Mean-flow period

口High-flow period

Figure 3. Spatial variations of discriminant indicators from spatial DA. Different letters (i.e., a, b, and c) of each water quality indicator in the same period represent significant differences among groups, $P<0.05$.

and Yanshi city) from 1998 to 2017. The results showed that during the low-flow period (i.e., December and January), the upper reaches (i.e., Luanchuan Country) only received $15.9 \mathrm{~mm}$ precipitation, much less than that in other regions. The river flow would also decrease owning to the decrease in precipitation during the low-flow period. Moreover, some river tributaries of the upper reaches (C3) were restricted by the mountainous terrain, and rivers were small and narrow, which increases the difficulty of pollutants the diffusing in the river water. The lowest values of temperature were presented in the low-flow period, ranging from -0.17 to $2.98{ }^{\circ} \mathrm{C}$ (Figure 4$)$. The temperature of the river water was also relatively low during this period, which affects the metabolism rate of the microorganisms that decompose pol- lutants. Thus, a large amount of pollution load would stay in the river water, resulting in pollution enrichment. In addition, during the investigation, we also noted that the domestic sewerage was not fully integrated into the sewerage treatment system in the upper reaches of the Yihe River Basin. Therefore, the direct discharge of domestic sewage was another major fac-tor of severe pollution during the low-flow period in the area. Finally, in the low-flow period, active sand mining activities were also one of the causes of river water pollution. Most of the precipitation in the Yihe River Basin was concentrated in summer and has a higher river runoff. Thus, pollutants (e.g., $\mathrm{NH}_{4}{ }^{+}-\mathrm{N}$ and TP) were diluted, and resulting in lower values of water quality monitored indicators during the high-flow period. 


\subsection{Spatial Variation Characteristics of Water Quality and Potential Pollute Source}

The gradient of urbanization is increasing from the upstream to the downstream in the Yihe River Basin. Land-use variations and land management methods that caused by human activities and urbanization development have significant effects on water quality changes (Varol et al., 2012; Wu et al., 2018). The water quality of the middle and upstream reaches of the Yihe river was superior to that of downstream reaches. Forest land has a pretty good weakening effect on water quality deterioration, and the roots and litter of vegetation have a strong retention and absorption effect of pollutants (Ji et al., 2015). Most of the mainstream (C2) belongs to hilly landforms. More than half of the rivers, canals and reservoirs in the study area were distributed on C2. Due to their strong capacity to purify pollutants, most of the water quality indicators monitored at $\mathrm{C} 2$ showed smaller averaged concentration values during the low- and high-flow periods. The lower reaches of the Yihe river flows through Yichuan Country and Yanshi Country (C1), its urbanization level was relatively higher than the middle and upper reaches. Therefore, in addition to the increase in point source pollution leading to the deterioration of river water quality, an increase in the proportion of impervious surfaces in the sub-basins would also endanger aquatic ecosystems and river water quality, which was consistent with previous study (Paul and Meyer, 2001). In urban areas, short-term heavy rainfall can promote contaminates matters to enter rivers through impervious surfaces. The underground drainage system in the city would further increase the peak flood flow and shorten the time for pollutants to enter the river. Besides, the accumulation of upstream pollutants leads to the deterioration of the water quality of downstream rivers after passing through the city. These reflect the impact of human socioeconomic activities and natural processes (e.g., precipitation) on river water quality. Therefore, in addition to the high pollution load of TP and $\mathrm{NH}_{4}{ }^{+}-\mathrm{N}$ in the water body due to the construction of the high-way in the upper reaches of the Yihe river during the mean-flow period, the water quality in the upper reaches (C3) and the midstream (e.g., Luhun Reservoir in C2) of the Yihe River Basin was better than the lower reaches $(\mathrm{C} 1)$ during the low-flow and high-flow period (Figures $2 \mathrm{~b}$ and 3 ).

Consequently, the temporal and spatial changes in water quality in the Yihe River Basin were affected by both human activities and natural factors. In addition to the effects of the construction of the high-way, the aquatic ecological control project, and cultivation, the temporal variation in water quality was also affected by climate change (e.g., precipitation and temperature), the variation in space was also restricted by natural environment characteristics such as topography.

\subsection{Representations of Spatial-Temporal Changes of the River Water Quality}

In terms of the representation of spatiotemporal changes in water quality in a river basin, the quantity and quality of monitoring water data in space were mostly presented through the discrete graphics (e.g., histogram, scatter diagram, and line chart) (Ravindra et al., 2003; Sundaray et al., 2006; Sun et al.,
2013; Wu et al., 2018). However, methods such as spatial interpolation were rarely used to draw contour maps on a two-dimensional plane to simulate the spatial difference in water quality (Wang et al., 2013). And little or no studies have used threedimensional (i.e., 3D) surface maps to describe the quantity, quality, density, and correlation of river water quality data at different sampling points. Rivers are 3D geographical things (Liu et al., 2019). Three-dimensional simulation of the spatial characteristics of river water quality data at different sampling points will be more visual, intuitive and more in line with people's habits of daily observation. The 3D kernel density surface graph can appropriately exaggerate the difference between the high and low values and can effectively highlight the differences between hot spots and regions, thereby making the display of thematic information more intuitive and diverse (Lu et al., 2017). In the future, related theories and techniques that expressed in three-dimensional such as kernel density estimation are desired to be explored and applied to the spatial mapping of river water quality. These are expected to provide more intoitive and scientific tools for river water environmental protection and water quality improvement.

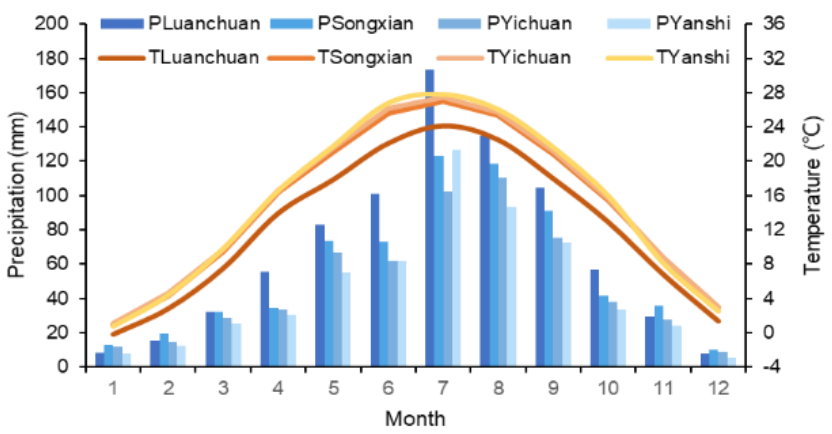

Figure 4. The monthly average precipitation (i.e., $P$ ) and temperature (i.e., $T$ ) of four weather stations (i.e., Luanchuan Country, Song Conntry, Yichuan Country, and Yanshi city) in Yihe River Basin from 1998 to 2017.

\section{Conclusions}

In this study, the spatiotemporal characteristics of river water quality were analyzed in 17 sub-basins in Yihe River Basin during low-, mean- and high-flow period based on the multivariate analysis methods. The potential pollution sources and contaminated areas were also identified according to the socioeconomic activities, meteorological data and the field investigations data in the Yihe River Basin in China. The results showed that: (1) PCA shows that the water quality in the Yihe River Basin was dominated by organic pollution during the low-flow period, followed by nitrogen pollution; nitrogen pollution was the influential indicators during mean-flow period, followed by phosphorus and organic pollution; nitrogen and organic was the main pollution during the high-flow period, respectively. (2) CA divides the sampling points of the Yihe River Basin from upstream to downstream into three categories (i.e., $\mathrm{C} 1, \mathrm{C} 2$ and $\mathrm{C} 3$ ). The results of DA verified that the accuracy of the CA was $94.1 \%$. It also showed good dimensionality reduction ability, that is, 
only five key water quality indicators (i.e., DO, EC, turbidity, $\mathrm{TP}$ and $\mathrm{NH}_{4}{ }^{+}-\mathrm{N}$ ) could reasonably reflect the water quality status in the Yihe River Basin. This can lessen the cost and number of recurring sampling indicators to optimize the sampling strategy. (3) Water pollution was most severe in the mean-flow period, followed by the low-flow period, and water quality in the highflow period was the best. The water quality shows a declining trend from upstream to downstream, and the water pollution located downstream (C1) was relatively severe. (4) The spatial and temporal variations of water quality were affected by human activities (e.g., the construction of the high-way, the aquatic ecological control project and cultivation), natural processes (e.g., precipitation and temperature) and natural environment characteristics (e.g., topography). Besides, related techniques of three-dimensional expressions such as nuclear density estimation can be used for the spatial mapping of river water quality in the future.

Acknowledgements. This research was supported by the National Key Research and Development Plan (2016YFA0601502), the General Project of National Natural Science Foundation of China (41771202, 41371195), and the Youth Project of National Natural Science Foundation of China (31600374).

\section{References}

Andrade, E.M.D, Palácio, H.A.Q, Souza, I.H., Leao, R., and Guerreiro, M.J. (2008). Land use effects in groundwater composition of an alluvial aquifer (Trussu River, Brazil) by multivariate techniques. Environmental Research, 106(2), 170-177. https://doi.org/10.1016/j. envres.2007.10.008

Bellos, D. and Sawidis, T. (2005). Chemical pollution monitoring of the river pinios (Thessalia-Greece). Journal of Environmental Management, 76(4), 282-292. https://doi.org/10.1016/j.jenvman.2005.01. 0276

Carpenter, S.R., Caraco, N.F., Correll, D.L., Howarth, R.W., Sharpley, A.N., and Smith, V.H. (1998). Nonpoint pollution of surface waters with phosphorus and nitrogen. Ecological Applications, 8(3), 559568. https://doi.org/10.2307/2641247

Chang, H. (2005). Spatial and temporal variations of water quality in the Han River and its tributaries, Seoul, Korea, 1993-2002. Water, Air, and Soil Pollution, 161(1-4), 267-284. https://doi.org/10.1007/ s11270-005-4286-7

Chang, N.N, Shiao, J.C., and Gong, G.C. (2012). Diversity of demersal fish in the East China Sea: Implication of eutrophication and fishery. Continental Shelf Research, 47, 42-54. https://doi.org/10.1016/ j.csr.2012.06.011

Chaudhuri, S., Roy, M., and Jain, A. (2020). Appraisal of WaSH (Water-Sanitation-Hygiene) Infrastructure using a Composite Index, Spatial Algorithms and Sociodemographic Correlates in Rural India. Journal of Environmental Informatics, 35(1), 1-22. https:// doi.org/10.3808/jei.201800398

Fang, X.B., Luo, L.P., Li, S., and Zhang, X.Z. (2013). Seasonal variations and source identification of surface water quality in Lanxi segment of Qiantang River. Acta Scientiae Circumstantiae, 33(7), 19801988. https://doi.org/10.13671/j.hjkxxb.2013.07.031

Gonzales-Inca, C.A., Kalliola, R., Kirkkala, T., and Lepistö, A. (2015). Multiscale landscape pattern affecting on stream water quality in agricultural watershed, SW Finland. Water Resources Management, 29(5), 1669-1682. https://doi.org/10.1007/s11269-014-0903-9

Henan Government. Development plan of modern comprehensive transportation system in Henan Province during the 13th five-year plan. http://www.henan.gov.cn/2017/04-11/248859.html (accessed July 13, 2017).

Hussain, S.M., Humane, S.S., Humane, S.K., Loganathan, P., and Fulmali, S.T. (2021). Distribution of sedimentary diatoms of Ooty Lake, Nilgiris District, Tamil Nadu, India: Implication on Water Quality Assessment using the Principal Component Analysis (PCA). Earth Science India, 13(4), 107-121. https://doi.org/10.31870/ESI.13.4.20 20.9

Igibah, C.E. and Tanko, J.A. (2019). Assessment of urban groundwater quality using Piper trilinear and multivariate techniques: A case study in the Abuja, North-central, Nigeria. Environmental Systems Research, 8(1), 14. https://doi.org/10.1186/s40068-019-0140-6

Ji, D.Q., Wen, Y., Wei, J.B., Wu, Z.F., Liu, Q., and Cheng, J. (2015). Relationships between landscape spatial characteristics and surface water quality in the Liu Xi River watershed. Acta Ecologica Sinica, 35(2), 246-253. https://doi.org/10.5846/stxb201303230496

Jia, L. and Zhang, Q.D. (2015). Dynamic effects of digging in different straws to the farmland's water nutrients. Journal of Southwest University of Science and Technology, 30(1), 50-53.

Kannel, P.R., Lee, S., Kanel, S.R., and Lee, Y.S. (2007). Spatial-temporal variation and comparative assessment of water qualities of urban river system: A case study of the river Bagmati (Nepal). Environmental Monitoring and Assessment, 129(1-3), 433-459. https:// doi.org/10.1007/s10661-006-9375-6

Li, C., Li, H.B, Gao, D., and Yang, X. (2017). Application of factor analysis and cluster analysis to water quality comprehensive evaluation on the Yellow River. Journal of Hubei University (Natural Science), 39(1), 72-75. https://doi.org/10.3969/j.issn.1000275.20 17.01.014

Li, X., Li, Y.Y, Li, Y., and Wu, J.S. (2018). Diversity and distribution of bacteria in a multistage surface flow constructed wetland to treat swine wastewater in sediments. Applied Microbiology and Biotechnology, 102(24), 10755-10765. https://doi.org/10.1007/s00253-01 8-9426-2

Lin, P.C., Li, S.Z., Qin, X.C., Cheng, W.X., and Liu, H.Z. (2019). Pattern of fish diversity and assemblage structure in the middle and lower reaches of the Yiluo River, Yellow River. Journal of Lake Sciences, 31(2), 482-492. https://doi.org/10.18307/2019.0217

Liu, C.W., Lin, K.H., and Kuo, Y.M. (2003). Application of factor analysis in the assessment of groundwater quality in a blackfoot disease area in Taiwan. Science of the Total Environment, 313(1-3), 77-89. https://doi.org/10.1016/S0048-9697(02)00683-6

Liu, H.M., Liu, L.Y., Ren, J.Y., Bian, Z.Q., and Ding, S.Y. (2017). Progress of quantitative analysis of ecosystem service flow. Chinese Journal of Applied Ecology, 28(8), 2723-2730. https://doi.org/10.13287/j.10 01-9332.201708.025

Liu, L., Ding, S.Y., Ren, J.Y., and Bian, Z.Q. (2019). Effects of landscape spatial heterogeneity on surface water quality service a case study in yihe river basin, henan province. Geographical Research, 38(6), 1527-1541. https://doi.org/10.11821/dlyj020180235

Lu, M., Yang, L., Wang, J., Huang, H., and Wang, J. (2017). Applications of pointgroup density cartography based on kernel density estimation. Engineering of Surveying and Mapping, 26(4), 70-74. https://doi.org/10.19349/j.cnki.issn1006-7949.2017.04.013

Luoyang Statistical Yearbook. Agrometeorological situation. Luoyang Statistical Yearbook, 237-239.

Ma, X.X., Wang, L.C., and Liao, L.L. (2015). Spatio-temporal characteristics and source identification of water pollutants in Wenruitang River watershed. Environment Science, 36(1), 64-71. https://doi. org/10.13227/j.hjkx.2015.01.009

Mavukkandy, M.O., Karmakar, S., and Harikumar, P.S. (2014). Assessment and rationalization of water quality monitoring network: A multivariate statistical approach to the Kabbini River (India). Environmental Science and Pollution Research, 21(17), 10045-10066. https://doi.org/10.1007/s11356-014-3000-y

Mir, R.A. and Gani, K.M. (2019). Water quality evaluation of the upper stretch of the river Jhelum using multivariate statistical techniques. 
Arabian Journal of Geosciences, 12(14), 445. https://doi.org/10.100 7/s12517-019-4578-7

Oketola, A.A., Adekolurejo, S.M., and Osibanjo, O. (2013). Water quality assessment of River Ogun using multivariate statistical techniques. Journal of Environmental Protection, 4(5), 466-479. https://doi.org/ $10.4236 /$ jep. 2013.45055

Oki, T. and Kanae, S. (2006). Global hydrological cycles and world water resources. Science, 313(5790), 1068-1072. https://doi.org/10. $1126 /$ science. 1128845

Paul, M.J. and Meyer, J.L. (2001). Streams in the urban landscape. Annual review of Ecology and Systematics, 32(1), 333-365. https://doi. org/10.1146/annurev.ecolsys.32.081501.114040

Pejman, A.H., Bidhendi, G.R.N., Karbassi, A.R., Mehrdadi, N., and Bidhendi, M.E. (2009). Evaluation of spatial and seasonal variations in surface water quality using multivariate statistical techniques. International Journal of Environmental Science and Technology, 6(3), 467-476. https://doi.org/10.1007/BF03326086

Pérez, C.J., Vega-Rodríguez, M.A., Reder, K., and Flörke, M. (2017). A Multi-Objective Artificial Bee Colony-based optimization approach to design water quality monitoring networks in river basins. Journal of Cleaner Production, 166, 579-589. https://doi.org/10.1016/j.jcle pro.2017.08.060

Putro, B., Kjeldsen, T.R., Hutchins, M.G., and Miller, J. (2016). An empirical investigation of climate and land-use effects on water quantity and quality in two urbanising catchments in the southern United Kingdom. Science of the Total Environment, 548-549, 164-172. https://doi.org/10.1016/j.scitotenv.2015.12.132

Ravindra, K. and Kaushik, A. (2003). Seasonal variations in physico-chemical characteristics of River Yamuna in Haryana and its ecological bestdesignated use. Journal of Environmental Monitoring, 5(3), 419-426. https://doi.org/10.1039/ b301723k

Ren, J.Y. (2018). The effects of landscape pattern on water quality in Yihe river basin. Master Dissertation, College of Environment and Planning, Henan University, Kaifeng, Henan Provence, China.

Ren, J.Y., Liu, H.M., Ding, S.Y., Wang, M.N., and Bian, Z.Q. (2017). Landscape pattern change and its driving mechanism in Yihe River basin, China. Chinese Journal of Applied Ecology, 28(8), 2611-2620. https://doi.org/10.13287/j.1001-9332.201708.023

Rigi, M.P., Shafiee, P., and Fatehi, S.M. (2019). Assessment and zoning of groundwater quality in Shiraz Plain using GIS. Asian Journal of Water, Environment and Pollution, 16(4), 87-96. https://doi.org/10. 3233/AJW190052

Russo, R.C., Thurston, R.V., and Emerson, K. (1981). Acute toxicity of nitrite to rainbow trout (Salmo gairdneri): Effects of $\mathrm{pH}$, nitrite species, and anion species. Canadian Journal of Fisheries and Aquatic Sciences, 38(4), 387-393. https://doi.org/10.1139/f81-054

Sajjad, R., He, J., and Quazi, H. (2018). Riverine water quality response to precipitation and its change. Environments, 5(1), 8. https://doi org/10.3390/environments5010008

Shen, Y.N, Yu, J., Chen, D.J., and Shi, Y.M. (2011). Response of stream pollution characteristics to catchment land cover in Cao-E River basin, China. Pedosphere, 21(1), 115-123. https://doi.org/10.1016/S10020160(10)60086-0

Shrestha, N.K. and Wang, J. (2020). Water quality management of a cold climate region watershed in changing climate. Journal of Environmental Informatics, 35(1), 56-80. https://doi.org/10.3808/jei.20 1900407

Shrestha, S. and Kazama, F. (2007). Assessment of surface water quality using multivariate statistical techniques: A case study of the fuji river basin, Japan. Environmental Modelling and Software, 22(4), 464475. https://doi.org/10.1016/j.envsoft.2006.02.001

Sickman, J.O., Zanoli, M.J., and Mann, H.L. (2007). Effects of urbanization on organic carbon loads in the Sacramento River, California. Water Resources Research, 43(11), 2578-2584. https://doi.org/10. 1029/2008WR006806

Simeonov, V., Stratis, J.A., Samara, C., Zachariadis, G., Voutsa, D.,
Anthemidis, A., Sofoniou, M., and Kouimtzis, T. (2003). Assessment of the surface water quality in Northern Greece. Water Research, 37(17), 4119-4124. https://doi.org/10.1016/S0043-1354(03)00398-1

Singh, K.P., Malik, A., and Singh, S. (2005) Water quality assessment and apportionment of pollution sources of Gomti river (India) using multivariate statistical techniques-a case study. Analytica Chimica Acta, 538(1-2), 355-374. https://doi.org/10.1016/j.aca.2005.02.006

Singh, K.P., Malik, A., Mohan, D., and Singh, S. (2004). Multivariate statistical techniques for the evaluation of spatial and temporal variations in water quality of Gomti River (India)-a case study. Water Research, 38(18), 3980-3992. https://doi.org/10.1016/j.watres.200 4.06.011

Sinha, E. and Michalak, A. M. (2016). Precipitation dominates interannual variability of riverine nitrogen loading across the continental United States. Environmental Science and Technology, 50(23), 1287412884. https://doi.org/10.1021/acs.est.6b04455

Sinha, E., Michalak, A.M., Calvin, K.V., and Lawrence, P.J. (2019). Societal decisions about climate mitigation will have dramatic impacts on eutrophication in the 21 st century. Nature Communications, 10(1), 939. https://doi.org/10.1038/s41467-019-08884-w

Solakian, J., Maggioni, V., Lodhi, A., and Godrej, A. (2019). Investigating the use of satellite-based precipitation products for monitoring water quality in the Occoquan watershed. Journal of Hydrology: Regional Studies, 26, 100630-100630. https://doi.org/10.1016/j.ejrh. 2019.100630

Strobl, R.O. and Robillard, P.D. (2008). Network design for water quality monitoring of surface freshwaters: A review. Journal of Environmental Management, 87(4), 639-648. https://doi.org/10.1016/j.jenv $\operatorname{man} .2007 .03 .001$

Sun, X., Zhang, H., Zhong, M., Wang, Z., and Huang, H. (2019). Analyses on the temporal and spatial characteristics of water quality in a seagoing river using multivariate statistical techniques: A case study in the duliujian river, China. International Journal of Environmental Research and Public Health, 16(6), 1020. https://doi.org/10. 3390/ijerph16061020

Sun, Y.X., Wu, G.X., Hu, H.Y., Guo, F., Wu, Y.H., and Guo, Y.M. (2013). Assessment of effluent quality of wastewater treatment plant in Kunming based on the percentile of standard compliance method. China Environmental Science, 33(6), 1113-1119. https://doi.org/10. 3969/j.issn.1000-6923.2013.06.021

Sundaray, S.K., Panda, U.C., Nayak, B.B., and Bhatta, D. (2006). Multivariate statistical techniques for the evaluation of spatial and temporal variations in water quality of the Mahanadi River-estuarine system (India)-a case study. Environmental Geochemistry and Health, 28(4), 317-330. https://doi.org/10.1007/s10653-005-9001-5

$\mathrm{Tu}$, J. (2009). Combined impact of climate and land use changes on streamflow and water quality in eastern massachusetts, USA. Journal of Hydrology, 379(3-4), 268-283. https://doi.org/10.1016/j.jhyd rol.2009.10.009

Tu, J. and Xia, Z.G. (2006). Assessing the impact of land use changes on water quality across multiple spatial scales in eastern Massachusetts. Middle States Geographer, 39, 34-42. https://doi.org/10.3126/jist.v 20i2.13949

Varol, M., Gökot, B., Bekleyen, A., and Sen, B. (2012). Water quality assessment and apportionment of pollution sources of Tigris River (Turkey) using multivariate statistical techniques-a case study. River Research and Applications, 28(9), 1428-1438. https://doi.org/10.100 2/rra.1533

Vega, M., Pardo, R., Barrado, E., and Debán, L. (1998). Assessment of seasonal and polluting effects on the quality of river water by exploratory data analysis. Water Research, 32(12), 3581-3592. https://doi.org/ 10.1016/S0043-1354(98)00138-9

Vitousek, P.M., Aber, J.D., Howarth, R.W., Likens, G.E., Matson, P.A., Schindler, D.W., Schlesinger, W.H., and Tilman, D.G. (1997). Human alteration of the global nitrogen cycle: Sources and consequences. Ecological Applications, 7(3), 737-750. https://doi.org/10.2307/226 
9431

Vörösmarty, C.J., McIntyre, P.B., Gessner, M.O., Dudgeon, D., Prusevich, A., Green, P., Glidden, S., Bunn, S.E., Sullivan, C.A., Liermann, C.R., and Davies, P.M. (2010). Global threats to human water security and river biodiversity. Nature, 467(7315), 555-561. https://doi.org/ 10.1038/nature09440

Wang, F., Gao, B.Y., Ma, D., Yue, Q.Y., and Wang, Q. (2016). Reduction of disinfection by-product precursors in reservoir water by coagulation and ultrafiltration. Environmental Science and Pollution Research, 23(22), 22914-22923. https://doi.org/10.1007/s11356-0 16-7496-1

Wang, F., Gao, B.Y., Yue, Q.Y., Fan, B., and Shen, X. (2017). Effects of ozonation, powdered activated carbon adsorption, and coagulation on the removal of disinfection by-product precursors in reservoir water. Environmental Science and Pollution Research, 24(21), 1794517954. https://doi.org/10.1007/s11356-017-9451-1

Wang, X., Wang, P.F., Wang, C., Chen, J., Hou, J., Miao, L.Z., Feng, T., and Yuan, Q.S. (2020). Taxonomic and functional responses of sediment bacterial community to anthropogenic disturbances in the Yarlung Tsangpo River on the Tibetan Plateau. Journal of Environmental Informatics, 35(1), 23-33. https://doi.org/10.3808/jei.201800403

Wang., R.Z., Xu, T.L., Yu, L.Z., Zhu, J.J., and Li, X.Y. (2013). Effects of land use types on surface water quality across an anthropogenic disturbance gradient in the upper reach of the Hun River, Northeast China. Environmental Monitoring and Assessment, 185(5), 41414151. https://doi.org/10.1007/s10661-012-2856-X

Wu, Z., Wang, X., Chen, Y., Cai, Y., and Deng, J. (2018). Assessing river water quality using water quality index in Lake Taihu Basin, China. Science of the Total Environment, 612, 914-922. https://doi. org/10.1016/j.scitotenv.2017.08.293

Xie, W.P., Yang, J.S., Yao, R.J., and Wang, X.P. (2020). Impact study of impoundment of the Three Gorges Reservoir on salt-water dynamics and soil salinity in the Yangtze River Estuary. Journal of Environmental Informatics, 36(1), 11-23. https://doi.org/10.3808/jei.20 2000432

Yan, N., Liu, W.B., Xie, H.T., Gao, L.R., Han, Y., Wang, M.G., and Li, H.F. (2016). Distribution and assessment of heavy metals in the surface sediment of Yellow River, China. Journal of Environmental Sciences, 39(1), 45-51. https://doi.org/10.1016/j.jes.2015.10.017

Yang, H.J., Shen, Z.M., Zhang, J.P., and Wang, W.H. (2007). Water quality characteristics along the course of the Huangpu River (China). Journal of Environmental Sciences, 19(10), 1193-1198. https://doi. org/10.1016/S1001-0742(07)60195-8

Yao, Y., Huang, G.H., An, C.J., Chen, X.J., Zhang, P., Xin, X.Y., Shen, J., and Agnew, J. (2020). Anaerobic digestion of livestock manure in cold regions: Technological advancements and global impacts. Renewable and Sustainable Energy Reviews, 119, 109494. https:// doi.org/10.1016/j.rser.2019.109494

Yu, B.Y., Wu, P., Sui, J., Ni, J., and Whitcombe, T. (2020). Variation of runoff and sediment transport in the Huai River-A case study. Journal of Environmental Informatics, 35(2), 138-147. https://doi. org/10.3808/jei.202000429

Yu, S.Y., Xu, Z.X., Wu, W., and Li, Y.L. (2014). Spatial variation of water quality and its response to landuse in the Beiluo River Basin. Acta Scientiae Circumstantiae, 34(5), 1309-1315. https://doi.org/ 10.13671/j.hjkxxb.2014.0202

Zhang, B., Song, X.F., Zhang, Y.H., Han, D.M., Tang, C.Y., Yu, Y.L., and Ma, Y. (2012). Hydrochemical characteristics and water quality assessment of surface water and groundwater in Songnen plain, Northeast China. Water Research, 46(8), 2737-2748. https://doi.org/10.10 16/j.watres.2012.02.033

Zhang, X., Zhou, L., and Liu, Y.Q. (2018). Modeling land use changes and their impacts on non-point source pollution in a southeast China coastal watershed. International Journal of Environmental Research and Public Health, 15(8), 1593. https://doi.org/10.3390/ijerph1508 1593

Zhou, F., Hao, Z.J., and Guo, H.C. (2007). Temporal and spatial distribution patterns of marine water quality in Eastern Hong Kong. Acta Scientiae Circumstantiae, 27(9), 1517-1524. https://doi.org/10.332 1/j.issn:0253-2468.2007.09.018

Zhu, L., Wang, Y.N., Han, M., Zhu, Y., Yu, H.B., and Song, Y. (2018). Spatio-temporal distribution of water quality and source identification of pollution in Wushui River Basin. Acta Scientiae Circumstantiae, 38(6), 2150-2156. https://doi.org/10.13671/j.hjkxxb.2017.0345 